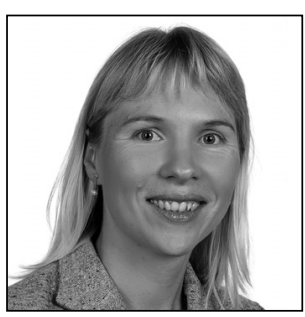

Karin Sein

Dr. iur., Docent of Civil Law University of Tartu

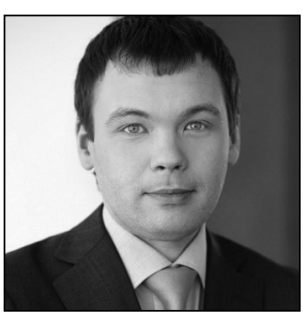

Urmas Volens

Dr. iur., Lecturer of Civil Law

University of Tartu

Specialist Counsel, Sorainen Law Firm

\title{
Legal Problems and Regulations related to Easy-access Non-secured Consumer Loans in Estonia
}

\section{Introduction}

Easy-access non-secured consumer loans (instant loans) are a fairly new phenomenon in the Estonian credit market. Providers of this variety of product do not have to follow any specific regulations. Instant loans typically have a short maturity term, the amount generally does not exceed EUR 1,00o, and the loans are provided by private enterprises not registered as credit institutions.

On account of the rapid advances of technology in recent years, instant-loan providers have been able to make it exceptionally easy for anyone to apply for such loans. The providers are open for applications for long hours, and often one can apply for a loan simply by sending a text message (SMS) from a previously identified mobile phone. In contrast to operations involving a commercial bank, wherein responding to a loan application may take up to five days, providers of instant loans give their answer in minutes. For example, in the case of instant-loan provider Credit $24^{*}{ }^{2}$, the offices are open from $8 \mathrm{am}$ to $10 \mathrm{pm}$, and a potential client who does not have access to electronic channels can simply fill in a form in a Maxima supermarket.

The market for instant loans is continuously and rapidly growing, so there are insufficient statistics describing the current situation. In addition, the overall debt of Estonian households is continuously growing. Households in Estonia generally do not have experience from previous recessions of how to handle debtservicing problems, as household debt was modest until the economic boom of 2004-2007. ${ }^{* 3}$ According to the annual survey conducted by TNS Emor, debt-servicing payments by Estonian households increased from 2006 to 2009, when $23 \%$ of indebted households had a debt-servicing level higher than $30 \%$ of their disposable income. ${ }^{*}$ There are some indirect statistics also, according to which approximately three per cent of the total population took out an SMS loan in 2008-2009. One of the debt advisers explained that in

1 This article is prepared within the framework of the project EMP205, Topical Issues of Consumer Credit in Estonia and Norway. The authors are indebted to Heili Püümann, stud. iur., without whom the publication of this article would not have been possible.

2 See its Web page at http://www.credit24.ee/ (most recently accessed on 31.1.2014).

3 K. Staehr, M. Kukk. The over-indebtedness of European households: Updated mapping of the situation, nature and causes, effects and initiatives for alleviating its impact. - Country Report Estonia, 19.12.2012, p. 27.

4 Ibid., p. 24. 
2008-2009 roughly a third of the debt-counselling cases involved clients who had accumulated arrears on SMS loans. ${ }^{*} 5$ The Ministry of Finance, however, estimates that at least 100,00o residents (out of Estonia's population of 1.3 million) have obtained instant loans. ${ }^{*}$ According to information from the register of 'payment disorders' supplied to the Ministry of Economic Affairs and Communications in October 2013, there are 34,047 individuals who have a payment disorder resulting from an instant loan or other consumer credit. ${ }^{*}$ It has been reported that the number of clients of instant-loan providers is continuously growing (mainly in the north-eastern part of Estonia and among the 25-30 and 55-60 age brackets). ${ }^{*}$

Regardless of the absence of precise statistical data, one can state that consumer over-indebtedness connected with instant loans is currently a very topical matter in Estonia.

This article analyses the current market situation involving instant loans in Estonia and social problems related to them. Firstly, the authors provide an overview of the legal issues that have not yet seen full harmonisation via the European consumer-credit legislation and that are specific to thisparticular type of credit product in Estonia. Furthermore, the article covers the market situation and estimates related to the credit products active in the market and possible numbers of creditors. Because there is no direct supervision of instant-loan providers, the authors are able to provide only unofficial and estimated figures characterising the problems. Then, the second part of the article provides a legal and institutional overview of the instant-loan market. The third and fourth parts describe the consumer-protection measures currently in force in Estonia and assess whether those measures have been functioning efficiently in practice. Finally, the ongoing discussions of further legislative measures are described and the associated legislative proposals evaluated.

\section{The market situation and statistics}

\subsection{Overview of the creditors and consumers}

Instant-loan providers are not supervised by Estonia's Financial Supervision Authority (FSA). The FSA monitors only credit institutions - that is, entities whose main activities are to give out loans and to accept deposits. ${ }^{*}$ Since the instant-loan providers do not accept deposits, they are not regarded as credit institutions and hence are not subject to supervision by the FSA.

The providers of instant loans are regarded as private creditors, and there is no special supervision provided by law. They are subject only to the monitoring of the Estonian Consumer Protection Board (CPB). The CPB follows the Consumer Protection Act ${ }^{*} 10$ (CPA), which, in general, regulates the provision of services or sale of products to customers. The CPB has only general supervisory power with respect to loan providers, and it does not have the right to intervene in the relationship between the parties to the loan contract. Therefore, eventually it is for the courts to decide whether a particular contract between a consumer and a lender is valid or not and whether the lender has the right to claim for payment of the related penalties, interest, and additional costs from the customer.

The problems related to instant loans became increasingly topical for the Estonian public in 20042007, when there was a considerable upturn in the instant-loan-provision market. It is remarkable that over 2006-2007 the total marketing costs of SMS-loan providers were comparable to the total marketing costs of the commercial banks active in Estonia. The extensive promotion of instant loans stopped in 2008, once default on debts had started to increase amidst global financial crisis. The instant-loan market

Ibid., p. 26.

6 Ministry of Economic Affairs and Communications (Majandus- jaKommunikatsiooniministeerium). Kiirlaenuturg - analüüs ja ettepanekud ['The instant-loan market - analysis and proposals'], p. 8. Available at http://www.mkm.ee/ public/kiirlanuturg_analyys_ja_ettepanekud.pdf (most recently accessed on 24.4.2013) (in Estonian).

7 Chancellery of the Riigikogu, department of law and analytics (Riigikogu kantselei õigus- ja analüüsiosakond). Kiirlaenud olemus, probleemid ja reguleerimisvõimalused ['Fast loans - their nature, problems, and options for regulations']. - Riigikogu kantselei õigus-ja analüüsiosakond, 21.10.2013 (No. 21). Available at http://www.riigikogu.ee/doc.php?177395 (most recently accessed on 31.1.2014) (in Estonian).

8 Kiirlaenuturg - analüüs ja ettepanekud (see Note 6), p. 8.

9 Credit Institutions Act (Krediidiasutusteseadus). - RT I, 23.12.2013, 30 (in Estonian).

According to $\$ 3$ (1) of the Credit Institutions Act, a credit institution is a company the principal and permanent economic activity of which is to receive cash deposits and other repayable funds from the public and to grant loans for its own account and provide other financing.

10 Consumer Protection Act (Tarbijakaitseseadus). - RT I, 31.12.2013, 7 (in Estonian). 
resumed its expansion in 2012-2013. According to publicly available financial reports from the loan providers, the annual growth of the market has been as great as 50\%. ${ }^{* 11}$ Working from data from the register of payment disorders, the Ministry of Economic Affairs and Communications assesses the size of the market to be approximately EUR 118 million per year and concludes also that the last two years have seen the size of that market increase by approximately $30 \%$ per year. ${ }^{{ }^{12}}$

Because there is neither a registration obligation nor official statistical information about the exact number of borrowers, it is only possible to provide some estimated values. The share of electronic retail lenders in the retail lending market as a whole is estimated at about $16 \% .{ }^{*}{ }^{13}$ In the assessment of the Ministry of Finance, the number of loan providers is approximately 100, but almost $90 \%$ of the loans are provided by 30 companies ${ }^{*}{ }^{14}$ This leads one to conclude that the instant-loan market is heavily concentrated with a few major players. During the period 2010-2012, the six biggest instant loan providers were SMSLaen AS, Placet Group OÜ (SMS Money), Folkia AS Eestifiliaal (Monetti), MCM Finance Estonia OÜ (Credit24), Hüpoteeklaen OÜ, and MiniCredit AS. In that period, the highest net profit reported by an instant-loan company was EUR 1.5 million. ${ }^{*}{ }^{15}$ Characteristic of the loan products of the leaders active in this market are high interest rates and a high annual percentage rate of charge (APRC); for example, for lending of EUR 300 to a regular customer of Yes Credit for one month, the APRC is $1355.19 \%$. For lending of the same amount from Monetti for a month, the APRC is $791.61 \%$ and from SMS-Laen it is $544.64 \%$. In comparison, the APRC for a 2,000-euro loan for four years from the bank SEB is approximately $18.54 \%$.

The Ministry of Economic Affairs and Communications has conducted interviews with debt counsellors in order to create a profile of an average instant-loan client. Consumer-credit debt is a problem mostly for people who have a lower level of education; debtors with a higher education are a very rare phenomenon. The majority of the debtors are unemployed, beneficiaries of subsistence funding, or persons receiving pension due to incapacity for work. The main reasons for taking out an instant loan are need to cover subsistence expenses, need to buy necessities, and need to cover other debts. As an alarming trend the debt counsellors note many young people applying for instant loans while in an intoxicated state at parties. ${ }^{*} 16$

\subsection{Products on the market}

Instant-loan providers offer several distinct credit products: instant loans, SMS loans, loans for small sums, and other consumer loans. These other consumer loans too, such as those involving traditional credit cards, qualify as non-secured loans, but some of the requirements involved in application for those traditional products differ from those applicable for the other products mentioned. An 'instant loan' is characterised by its short duration and small amount. Often, an application for an instant loan can be submitted via the Internet.

An SMS loan is a type of instant loan that can be applied for through sending of a message by SMS to the provider. ${ }^{*}{ }^{*}$ Until the beginning of 2008, instant-loan providers in Estonia were allowed to identify customers without direct contact with them (for example, through a bank link). Since concerns about malpractice were serious, the law was amended in early $2008^{*}{ }^{*} 8$; under the regulations now in effect, the applicant has to be identified by the lender at least once in person ${ }^{* 19}$. This amendment to the law was a first step toward more responsible practices in electronic retail lending. After its adoption, most lenders implemented some changes of procedure, usually arranging things such that the first-time identification is done either in the

\footnotetext{
M. Kukk. What do we know about SMS loans / fast loans in Estonia? Tallinn University of Technology, 17.9.2013.

Kiirlaenuturg - analüüs ja ettepanekud (see Note 6), p. 3.

Ibid., p. 7 .

Ibid.

Ibid., p. 5 .

Ibid., pp. 13-14.

See further discussion of these modern credit products in K. Saare et al. Protection of consumer rights in SMS loan agreements. - European Review of Private Law, 2010/18, pp. 129-131.

18 I. Ulst. Balancing the Rights of Consumers and Service Providers in Electronic Retail Lending in Estonia. Tartu Ülikooli Kirjastus 2011, p. 21.

19 The Money Laundering and Terrorist Financing Prevention Act (Rahapesu ja terrorismi rahastamise tõkestamise seadus). RT I, 8.5.2012, 5 (in Estonian).
} 
office of the lender or by means of a courier service. ${ }^{{ }^{2} 20}$ The government has now recommenced discussion regarding possible additional amendments to the regulations, and various analyses are being carried out by individual ministries.

Several instant-loan providers offer some unusual kinds of credit products, such as a loan that a person can be granted in cash. Getting the amount in cash has two 'advantages'. Firstly, if the creditor pays out the loan in cash, there will be no record of it on the consumer's bank statement. That element is very important with regard to confidentiality. Under the usual bank practices ${ }^{{ }^{21}}$ in Estonia, it is difficult for a person to get credit from a commercial bank if having taken out an instant loan. Before the 'loan in cash' product appeared on the market, some consumers were hesitant to obtain an instant loan because they were aware of the problems that could occur in the future upon application for a loan from a bank. In contrast, there were no problems related to signing the 'loan in cash' contract: the product offers full confidentiality and allows clients to get an instant loan 'without consequences'. Secondly, a loan of this type can be taken out even by a person whose bank account has been seized by the bailiff, with all the payments to that account being applied directly for repayment of previous debts. If the loan is paid out in cash, the person receives it regardless of bank-account status.

On account of the number of instant-loan providers in Estonia, a Web site ${ }^{{ }^{22}}$ has been developed in a commercial initiative to allow clients to obtain a better overview of the various creditors. That site offers a possibility to get acquainted with all possible creditors and the loan products on the market. The Web site also gives potential clients an opportunity to submit requests to all of the creditors and compare the offers before choosing one. On one hand, this gives potential clients the opportunity to get a comprehensive overview of all possible products and to find the best offer; on the other hand, Web sites of this sort are another way for instant-loan providers to advertise their products and promote the understanding that credit is easily available.

\section{Legal and institutional overview}

\subsection{Legal overview}

The framework regulation that is binding for consumer credit can be divided into administrative measures and contractual measures. Supervision of administrative measures is exercised by the CPB and, in cases of disagreement, by administrative courts. The contractual measures can be implemented by the parties through actions in civil courts.

The administrative measures are regulated mainly by the Consumer Protection Act (CPA) and the Advertising Act (AA). ${ }^{*}{ }^{23}$ The CPA regulates the offering, sale, and marketing of goods or services to consumers by traders; specifies the rights of consumers as purchasers or users of goods or services in general; and provides for the organisation and supervision of consumer protection and liability for violations. The aim with the AA is to restrict the advertising activity of the creditors and reduce the likelihood of the loan providers creating an illusion of easy money. If consumer credit is granted by a credit institution, the provisions of the Credit Institutions Act (CIA) too are binding for the relevant creditor.

The contractual aspects of credit transactions are regulated by the Law of Obligations Act (LOA) ${ }^{* 24}$, among them the norms implementing the EU Consumer Credit Directive (CCD) ${ }^{*} 25$. The unconscionability doctrine under which usurious credit contracts are restricted can be found in the General Part of the Civil Code Act (GPCCA) ${ }^{* 26}$. The procedural aspects of enforcing the claims arising from consumer-credit contracts are to a great extent set forth in the Civil Procedure Code (CPC). ${ }^{*}{ }^{27}$ It must be stressed that the order-for-

\footnotetext{
I. Ulst (see Note 18), p. 21.

For example, leading banks in Estonia SEB and Swedbank.

See http://www.parimintress.ee/ or http://www.heaintress.ee/ (most recently accessed on 26.2.1014).

Advertising Act (Reklaamiseadus). - RT I, 11.6.2013, 6 (in Estonian).

Law of Obligations Act (Võlaõigusseadus). - RT I, 8.7.2011, 21 (in Estonian).

5 Directive 2008/48/EC of the European Parliament and of the Council of 23 April 2008 on credit agreements for consumers and repealing Council Directive 87/102/EEC, OJ L 133/66, 22.5.2008.

26 General Part of the Civil Code Act (Tsiviilseadustiku üldosa seadus). - RT I, 6.12.2010, 12 (in Estonian).

27 Civil Procedure Code (Tsiviilkohtumenetluse seadustik). - RT I, 22.3.2013, 16 (in Estonian).
} 
payment procedure is used extensively by creditors ${ }^{* 28}$. It is common practice for instant-loan providers to use this procedure for asserting their claims against consumers: according to the statistics of the Ministry of Economic Affairs andCommunications, $80 \%$ of all claims related to instant loans are asserted via the orderfor-payment procedure. ${ }^{{ }^{2} 29}$ It is a faster and less expensive procedure for the claimant than others, as it is implemented without court hearings. Notification about the claim and a debt-repayment proposal are sent to the debtor by post. If the debtor does not respond, the court decides on the debt-enforcement measures to be applied, without the debtor's involvement. The amounts that are claimed in court can substantially exceed that of the initial loan.

A third group of relevant regulations come into play, to do with the results of consumer over-indebtedness. In the event of insolvency of a private person or a household, there is a possibility for bankruptcy proceedings or restructuring of debts. In 2011, the Debt Restructuring and Debt Protection Act (DRDPA) ${ }^{*} 30$ entered into force, with the intent being to offer alternatives to bankruptcy for indebted individuals. The DRDPA stipulates that natural persons can turn to the courts to apply for restructuring of personal debts for purposes of overcoming the solvency problems and avoiding bankruptcy. The debtor has to provide a sustainable debt-restructuring plan demonstrating ability to pay at least some of the debt due. The debtor has to cover all the associated costs, including the court fees and the costs of the advisory service. The aim with the DRDPA was to offer natural persons with temporary payment issues a possibility to restructure the debt and to help them through solvency problems ${ }^{*}{ }^{31}$; however, in practice, the protection provided by the DRDPA seems not to be sufficient. According to the statistics of the Ministry of Justice, from April 2009 to November 2013 only 102 restructuring applications were filed with the courts, 92 of which have proceeded to processing. Of the applications processed, only seven were fully or partially approved by the court. ${ }^{*}{ }^{2}$

The Bankruptcy Act ${ }^{*} 3$ (BA), from 2004, provides a possibility for natural person to commence bankruptcy proceedings and eventually be released from the debts. ${ }^{*} 34$ In general, the rules of bankruptcy proceedings for a natural person are similar to those applicable to the equivalent proceedings for legal persons $^{*} 35$, with the main difference being that for natural persons the law provides for debt-release procedure. At the request of a debtor, the court can decide on the release of said debtor from his or her obligations that were not performed during the bankruptcy proceedings by a ruling five years after commencement of proceedings for the release of the debtor from his or her obligations (see $\$ 175$ (1) of the BA). Taking into account the circumstances the court may release a debtor who has been performing his or her obligations duly from his or her obligations of even earlier but not before three years have passed from commencement of the proceedings (again, see $\S 175(1)^{1}$ of the BA).

\subsection{Institutional overview}

Since instant-loan providers are not credit institutions, their business practices are neither standardised nor regulated as those of credit institutions are. They are not obliged to disclose any specific information describing their activities to a supervisor, and they are bound only by general business regulations.

The majority of the instant-loan providers do not fall under the jurisdiction of the FSA. Therefore, the only relevant supervisory authority is the $\mathrm{CPB}$, under whose jurisdiction falls supervision of the fulfilment of the $\mathrm{CPA}$ and the $\mathrm{AA}$. According to the $\mathrm{AA}$, the $\mathrm{CPB}$ has the right to supervise the compliance of

28 Section 481 et seq. of the Civil Procedure Code. The procedure is similar to the order-for-payment procedure under Regulation (EC) No 1896/2006 of the European Parliament and of the Council creating a European order for payment procedure. OJ L 399, 30.12.2006, pp. 1-32.

29 Kiirlaenuturg- analüüs ja ettepanekud (see Note 6), p. 13.

30 Debt Restructuring and Debt Protection Act (Võlgade ümberkujundamise ja võlakaitse seadus). - RT I, 6.12.2010, 1 (in Estonian).

${ }^{31}$ Võlgade ümberkujundamise ja võlakaitse seaduse eelnõu seletuskiri ['Explanatory memorandum on the Debt Restructuring and Debt Protection Act]. Available at http://www.riigikogu.ee/?page=eelnou\&op=ems2\&emshelp=true\&eid=100409 $5 \& u=20140130162250$ (most recently accessed on 31.1.2014) (in Estonian).

32 Statistics provided by the Ministry of Justice that are related to implementing of the Debt Restructuring and Debt Protection Act. Statistics as of 2013 (the above-mentioned statistics are in the possession of the authors).

33 Bankruptcy Act (Pankrotiseadus). - RT I, 23.12.2013, 54 (in Estonian).

34 Chapter 11 of the BA.

35 M. Varusk. Füüsilise isiku pankrotimenetlus ['Bankruptcy proceedings for natural persons']. Available at http://www.just. ee/49515 31.01.2014 (most recently accessed on 26.2.2014) (in Estonian). 
advertising with the requirements specified by law. In its supervision, the CPB has the right to check the compliance of advertising with the requirements set by the law (see §31 (1) 1) of the AA), issue oral warnings to the person who commissioned certain advertising and the advertiser or the producer of the advertisement in question, and draw said persons' attention to any failure to comply with the requirements of the AA (see $\S 31$ (1) 5) of the AA).

The CPB is also entitled to issue guidelines of an advisory nature-i.e., non-binding recommendations. In 2012, the CPB issued advisory guidelines for consumer-credit providers, ${ }^{*} 6$ in which it explained the obligations of responsible lending and laid down some rules for implementation of the reasonable lending principle.

\section{Measures}

\subsection{Administrative measures}

\subsubsection{Licensing}

There are currently no licensing measures or regulations in place for instant-loan providers under Estonian law, as the licensing system and supervision by the FSA are applicable only to credit institutions. However, during recent discussions the question has been raised of whether imposing licensing requirement could have a positive influence on the instant-credit market. Even the Supreme Court has stressed that the legislator should introduce more stringent administrative control requirements for the consumer-credit providers $^{*} 37$ and currently the Ministry of Finance is working on a legal proposal introducing licensing requirements also to creditors other than banks.

Indeed, if instant-loan providers were obliged to have a licence, it would be possible to exercise more efficient supervision of them. This would aid in getting a better overview of the situation with instant-loan providers and statistics on them. Licensing measures could also offer the possibility to establish minimum requirements for operation (e.g., a minimum threshold for equity capital and requirements for members of the management board). Last but not least, the possibility of losing the licence would motivate the creditors to comply with the requirements for responsible lending practices.

\subsubsection{Marketing restrictions}

Estonian law sets some specific restrictions on advertising of financial services and some general requirements for marketing that also have an impact on the instant-loan market. In 2013, the legislator introduced additional provisions to the AA on advertising of financial services. One of the major problems connected with instant loans (and non-secured consumer credit in general) is that in their advertisements creditors create an illusion that lending is extremely easy and will even resolve personal financial problems. ${ }^{*} 8$ Recently, one of the most common commercial practices among many instant-loan creditors has been marketing the first loan as 'free': if taking out a loan under certain conditions (amount limits and conditions as to the time period), the consumer is obliged to repay only the principal amount of the loan later. The main purpose of that kind of practice is to attract new clients and to create a positive experience of the service.

The advertising restrictions-both general ones and those specific to financial services-are regulated in the AA. Under a general principle of the AA, advertising that in any way misleads or is likely to mislead the persons to whom it is directed or whom it reaches and that, by reason of its misleading nature, is likely to affect their economic behaviour or that, for those reasons, injures or is likely to injure a competitor of the person placing the advertising is prohibited. In accordance with the AA, therefore, an advertisement that

36 Tarbijakaitseamet (Consumer Protection Board). Juhend tarbijakrediidi pakkujatele ja vahendajatele ['Advisory guidelines for consumer-credit providers and retailers'], 22.11.2012 Available at http://www.tarbijakaitseamet.ee/sites/default/files/ failid/dokumendid/juhend_krediidiandjatele_vastutustundlik_laenamine_.pdf (most recently accessed on 30.1.2014) (in Estonian).

37 CCSCd 5.3.2014, 3-2-1-186-13, paragraph 25 (in Estonian).

38 For example, the advertisement from the Web page http://www.parimintress.ee/ 'After a long postponement of visiting the dentist, I decided to borrow the absent money and finally got my teeth repaired. Thanks to the Web site parimintress.ee, I found a very favourable loan, and I am truly grateful to them for that'. 
creates an impression that the non-secure easy-access loan is an easy solution for financial problems and has no serious consequences is prohibited.

In May 2013, an amendment was made to §29 (1) of the AA such that the rules on advertising by credit institutions are now extended to non-secured easy-access loan creditors. According to §29 (2) of the AA, an advertisement of financial services must include an invitation to examine the terms and conditions of the financial services and to consult an expert, if necessary. Any advertisement in which consumer credit is offered or the arrangement of consumer-credit contracts is offered must indicate the annual percentage rate of charge by way of a representative example (under §29 (3) of the AA). Further, an advertisement offering credit to a consumer has to be responsible, and the advertiser is not allowed to create an illusion that taking out consumer credit is risk-free and an easy solution to financial problems. Any advertisement in which consumer credit is offered or the arrangement of consumer-credit contracts is offered has to be responsible and balanced, and it may not suggest that consumer credit is a risk-free and simple opportunity to solve financial problems or induce consumers to ill-advised borrowing (see \$29 (7) of the AA). The information shall be presented in such a typeface and font size as, given ordinary attention, make it noticeable, understandable, and clearly distinguishable from other information.

According to the explanatory memorandum on the above-mentioned amendments to the AA, their goal is to prevent financial services from being advertised in a way that leads the consumer to take out credit unwisely. ${ }^{*}{ }^{39}$ Responsible and balanced advertising also means that information about possibilities and purposes of using the loan should not overshadow the information on the obligations and responsibilities that follow from using the consumer credit.

In a general requirement under the CPA, unfair and misleading commercial practices are prohibited (see §12, items 2 and 3 of the CPA). An unfair commercial practice is a practice that is contrary to good commercial usage. A commercial practice is misleading if it employs false information or if presentation of factually correct information deceives or is likely to deceive the average consumer and, in consequence of it, the average consumer makes a transaction decision that he or she would not have made otherwise or is likely to do so. So far, there is no Supreme Court case law related to misleading or unfair commercial practices in relation to credit transactions.

The CPB has the right to issue, within the limits of its competence, advisory guidelines on compliance with the requirements arising from legislation for consumer protection. In 2013, the CPB exercised this right and issued guidelines for application of the financial-service advertisement requirements that were designed to specify the definition of advertisement and financial services. For example, in a situation wherein the client has not asked for an offer of financial services, a 'personal offer' is to be considered an advertisement. ${ }^{*} 40$ Another aim with the guidelines is to specify the law's restrictions on the advertisement of financial services ${ }^{*} 41$, such as the obligation to publish a representative example. The service provider, when preparing a representative example through application of its best professional skills on the basis of the statistics and/or practice of the company, is responsible for classification of credit contracts and the authenticity of the data used. ${ }^{*}{ }^{2}$

According to the statistics provided by the CPB, that board has conducted 54 sets of proceedings in 2011 related to advertisement of financial services. Violation of the law has been asserted 24 times. In 2010, the board carried out 38 sets of proceedings related to advertisement of financial services and violations were asserted in 17 cases. ${ }^{*} 43$

One can conclude that restrictions related to advertisements are relatively efficient measures against the illusion of 'easy money'. It is more doubtful, however, whether the obligatory information in

39 Võlaõigusseaduse ja reklaamiseaduse muutmise seletuskiri ['Explanatory memorandum on the Act Amending the Law of Obligations Act and Advertising Act]. Available at http://www.riigikogu.ee/?op=ems\&page=eelnou\&eid=7df3d370-3b77-4cobbe6b-c73fffdo242b\& (most recently accessed on 18.1.2014) (in Estonian).

40 Tarbijakaitseamet (Consumer Protection Board). Guidelines for compliance with the requirements arising from legislation for consumer protection, 12.9.2013. Available at http://www.tarbijakaitseamet.ee/sites/default/files/failid/dokumendid/ guidelines_for_application_of_the_financial_service_advertisement_requirements-enters_into_force_01_12_2013.pdf (most recently accessed on 4.6.2014), p. 5 .

41 Ibid., p. 6.

42 Ibid., p. 8.

43 Tarbijakaitseamet (Consumer Protection Board). Tarbijakaitseameti aastaraamat 2012 ['Yearbook of the Consumer Protection Board 2012']. Available at http://www.tarbijakaitseamet.ee/en/node/304 (most recently accessed on 30.1.2014) (in Estonian). 
a financial-service advertisement really is able to ensure that an average reasonable person actually can understand the possible risks of an instant-loan contract. Recently during the political debate the question has been raised whether to ban the advertising of consumer loans in TV and radio all in all but the debate is still ongoing.

\subsubsection{The system of debt-counselling}

Debt-counselling as a public social service is not generally available in Estonia. However, there are three types of debt-counselling systems.

On the Web page created by the FSA, there is an interactive 'debt-counselling' application that helps a debtor to analyse his or her situation. ${ }^{*} 4$ The problem with Internet counselling is that it is not direct, it does not take into account the person's actual situation, and many people may not have access to the Internet.

The second category of debt-counselling involves NGOs offering counselling services on their own initiative and on their own conditions. There is no state supervision of these organisations, and the network of institutions is developed arbitrarily.

In a very limited extent, there are also debt-counselling services offered by the state and by the local governments. The Estonian Unemployment Insurance Fund offers personal counselling for unemployed persons with the purpose of helping the unemployed back to the labour market. ${ }^{*} 45$ One part of their personal counselling encompasses debt-counselling if necessary. In order to obtain such debt-counselling, the person has to be unemployed. In a one-time programme, the Ministry of Social Affairs also has carried out debt-counselling for persons who are not recorded as unemployed, but such programmes are rather exceptional.

Some local governments too provide debt-counselling as a part of their social services. One of the most successful of these is the local government of Tallinn, which has created the Tallinn Social Work Centre, whose services include debt-counselling. The service is aimed at individuals who have their registered domicile in Tallinn, and the counselling is offered free of charge. Since 2008, the Social Work Centre has been offering debt-counselling also to persons who are not residents of Tallinn, but in those cases the fee for the service is 19 EUR. ${ }^{*} 46$ If the debtor is directed to the Tallinn Social Work Centre by some other local government, the cost might be covered by that local government.

In conclusion one can state that debt-counselling service is not available as a general social service in Estonia. Therefore, the system of debt-counselling is not harmonised and is case-specific. The most accessible route to help is to use interactive debt-counselling Web sites. The indebted person also has the opportunity to utilise the help of NGOs, but there is no actual public supervision of these institutions. Debtcounselling organised by the state or local government is not systematic.

\subsubsection{The credit register}

Only a privately held negative credit register exists in Estonia. The register is maintained by a public limited company, AS Krediidiinfo, as one of its publicly available business services (the register of payment disorders). Under Estonian law, apart from general data-protection rules ${ }^{*} 47$, there is no special regulation on dissemination of debtors' data.

The register of payment disorders was created back in 2001 as a co-operation project of commercial banks in Estonia with the aim of offering creditors the possibility to make reasonable and appropriate credit decisions and also to help creditors to apply the reasonable lending principle. The register contains data of both natural persons and legal persons. The data are obtained from the users of the register or from other creditors. Information about when and on what grounds the debt arose, when the obligation ended, and the approximate amount of the debt is held in the register.

\footnotetext{
44 Võlanõustaja ['Debt counsellor'].Available at http://volanoustamine.minuraha.ee/files/v6lan6ustamine.pdf (most recently accessed on 31.1.2014) (in Estonian).

45 Tööturuteenused ja toetused ['Labour market services and benefits']. Available at http://www.sm.ee/tegevus/too-ja-toimetulek/tooturuteenused-ja-toetused.html (most recently accessed on 31.1.2014) (in Estonian).

46 The Tallinn Social Work Centre on the Internet: http://www.swcenter.ee/ (most recently accessed on 18.1.2014) (in Estonian).

47 Personal Data Protection Act (Isikuandmete kaitse seadus). - RT I, 30.12.2010, 11 (in Estonian).
} 
A payment disorder is entered in the public register when debt has arisen from breach of contract and not been settled within 45 days. The amount of the debt has to be at least EUR 30, inclusive of interest and the penalty for late payment. If a person has many separate debts, the register shows the balance of the debts. The balance of a debt is updated in line with the actual amount of debt. An active payment disorder will be removed from the register when all obligations that have arisen in relation to the contract are fulfilled, but information about previous debts entered in the register remains there after the debt is paid. The information on previous payment disorders remains available for seven years in cases of legal persons and three years for natural persons. ${ }^{*} 48$ Exceptionally, the payment disorders of natural persons that are entered in the register by banks will, according to the internal rules of the register, be available for five years. ${ }^{*} 49$ Inserting data in the Krediidiinfo database presumes that the creditor has a contract with AS Krediidiinfo and that the contract that is the basis for the debt allows the lender to forward the data to the register of payment disorders. The consumer's consent is usually obtained via the standard terms. The information about legal persons is publicly available for everyone, but obtaining access to the information about private persons requires one to have a legitimate interest. ${ }^{*} 50$

There has been some discussion about the need for creating a positive credit register-i.e., a register that would include all the credit information, total income of private persons, and obligations that are officially registered. It is argued that a positive credit register would offer a possibility to focus on actual creditworthiness and its sustainability by the applicant. ${ }^{*}{ }^{1}$ The greatest impact of use of a positive credit register would probably be a decrease in the credit risk for creditors. It would also aid in implementation of the principle of responsible lending. It is suggested that a positive credit register would help to decrease the amount of unpaid loans: surveys by the World Bank Group and comparison of Estonia with other countries suggest that a positive credit register could decrease unpaid loans by $50 \%$ and consumer loans' interest by about $30 \% .{ }^{*}{ }^{2}$ On the other hand, creation of a positive register raises privacy concerns, and there has not yet been a political decision on this issue

\subsubsection{The principle of responsible lending}

The principle of responsible lending and the obligations arising therefrom are mostly a result of implementation of the Consumer Credit Directive, although for credit institutions an obligation to assess a prospective borrower's creditworthiness was introduced back in 2007 in $\$ 83$ (3) of the CIA. The main obligations related to the responsible lending principle are provided by the LOA and AA. The principle of responsible lending is not defined in Estonian law but can be described in terms of the various obligations of the creditor in the pre-contractual phase. The main obligations related to responsible lending are the obligation to acquire information that gives the creditor the possibility of assessing the creditworthiness of the customer, judge creditworthiness, and give the consumer sufficient information to enable him or her to assess whether the proposed consumer-credit contract corresponds to his or her needs and financial situation (under $\$ 403^{2}$ (1) of the LOA). The burden of proof of compliance with those obligations lies with the creditor (see $\$ 403^{2}$ ( 7 ) of the LOA).

In assessment of the creditworthiness of a consumer, the creditor should adhere to due diligence and take into consideration all the circumstances known to the creditor that may have an impact on the consumer's ability to repay the credit under the terms and conditions agreed upon in the contract, including the consumer's financial situation, regular income, other financial obligations, performance of earlier payment obligations, and the impact of a potential increase in the financial obligations arising from the consumercredit contract, by means of determining the extent of the required assessment operations in light of the

48 Ibid., $§ 6(11)$.

49 Eraisiku maksehäirete sisestamine ['Recording of the payment disorders of private persons']. Available at http://www. krediidiinfo.ee/index.php?m=365 (most recently accessed on 25.2.2014) (in Estonian).

50 Eraisiku maksehäirete vaatamine ['Examining the payment disorders of private persons']. Available at http://www.krediidiinfo.ee/index.php?m=301 (most recently accessed on 25.2.2014) (in Estonian).

51 K. Saar. Positiivne krediidiregister teeb laenud odavamaks ['The positive credit register decreases the cost of credit']. Äripäev, 15.10.2013. Available at http://www.aripaev.ee/?PublicationId=31503ED6-39D4-4163-9D98-74AA1E3959CE\&p aperarticleid=BBA4330D-3E54-433F-A3A9-2CoFCE535OAF (most recently accessed on 25.2.2014) (in Estonian).

52 Ibid. See also: Krediidiinfo. Eraisikute krediidiregistri võimalikkusest Eestis ['On the possibility of a credit register for private persons'], 12.11.2012. Available at http://blog.krediidiinfo.ee/2012/11/eraisikute-krediidiregistri-voimalikkusest-eestis/ (most recently accessed on 25.2.2014) (in Estonian). 
terms and conditions of the consumer-credit contract, the consumer data available, and the amount of the financial commitment undertaken (see $\$ 403^{2}(2)$ of the LOA).

Both the FSA and the CPB have issued guidelines on implementation of the responsible lending principle. According to the guidelines of the FSA, the credit institution should assess whether the customer would be able to repay the loan from his or her income/salary and whether the customer's income will be viable in the future. Viability of repaying the loan means that the customer is able to pay back the loan out of his or her salary or savings without the need to liquidate the collateral. ${ }^{*} 53$ The CPB too has emphasised the importance of viable lending. According to the CPB's guidelines, the creditor has to take the credit decision primarily on the basis of the viability of paying. ${ }^{*} 4$

In 2010, the CPB received 692 consumer complaints related to consumer credit. The number for 2011 was 572. ${ }^{*} 5$ The main reason for an injunction on consumer-credit providers was related to hardly understandable legal language in the standard terms and unreasonably high fees for premature termination of the contract. Statistics show that the complaints received by CPB in 2010 related to the principle of responsible lending and has detected 30 financial-service providers who failed to meet the responsible lending requirements. ${ }^{*} 56$

In the explanatory memorandum on the act implementing the Consumer Credit Directive, it is stated that the lender has the obligation to assess the client's financial situation during the counselling on the loan. ${ }^{*}$ In $\$ 403^{2}$ (1) of the LOA, the legislator has clearly connected Subsection 6 and Article 8 of the Consumer Credit Directive with each other, as a result of which it can be presumed that the legislator has foreseen the consumer's counselling in accordance with his or her creditworthiness. ${ }^{*}{ }^{8}$ In Estonian law, the obligations of the parties arising from the responsible lending principle are regulated as part of the pre-contractual obligations, with the goal of minimising the information asymmetry between the parties. ${ }^{*} 59$

It has to be taken into account that, according to the law, the consumer has to receive enough explanations. What is enough is not defined in the law and has to be determined case-specifically. The extent of the explanations is dependent upon the consumer, the conditions of the offer, and the complexity of the terms and conditions. ${ }^{*} 60$ According to the guidelines of the Consumer Protection Board, the scope of the explanations depends on the specific credit product and on the previous experience of the consumer. The creditor is obliged to clarify the consumer's need and wish to get more information about the contract. It is not allowed for the creditor to encourage the consumer not to submit information that is necessary for the process of evaluating consumercreditworthiness. Also, the possibility of asking questions and getting sufficient answers from the creditor has to be ensured for the client. ${ }^{* 61}$

If the credit provider does not honour the obligations specified by law, the Consumer Protection Board can issue a prescription as to how the practice of the creditor should be changed (see $\S 41$ (1), item 1 of the CPA). According to § 23 (4) of the Law Enforcement Act ${ }^{*} 62$ that is in force since 01 July 2014 the upper limit of possible penalty payment is 9600 euros.This is remarkably higher than the 640 euros that was the upper limit until the recent amendments.

53 Finantsinspektsiooni soovituslik juhend ['Recommended guidelines of the Financial Supervision Authority']. Vastutustundliku laenamise nõuded ['Requirements on responsible lending'], p. 5. Available at http://www.fi.ee/public/Soovituslik_juhend_Vastutustundlik_laenamine.pdf (most recently accessed on 18.1.2014) (in Estonian).

54 Tarbijakaitseamet (see Note 36).

55 Tarbijakaitseamet (the Consumer Protection Board). Tarbijakaitseameti aastaraamat 2011 ['Yearbook of the Consumer Protection Board 2011'], p. 10.Available at http://www.tarbijakaitseamet.ee/en/node/304 (most recently accessed on 30.1.2014) (in Estonian).

56 Tarbijakaitseamet (see Note 43), p. 14.

57 Võlaõigusseaduse ja teiste seaduste muutmise seaduse seletuskiri ['Explanatory memorandum on the act implementing the Consumer Credit Directive'], p. 26. Available at http://www.riigikogu.ee/?page=eelnou\&op=ems\&emshelp=true\&e $\mathrm{id}=1033413 \& \mathrm{u}=20110306003000$ (most recently accessed on 18.1.2014) (in Estonian).

58 Ibid., p. 26.

59 K. Koll. Vastutustundliku laenamise põhimõte ['The principle of responsible lending']. Available at http://www.just.ee/orb. aw/class=file/action=preview/id=55659/Kristiina + Koll.+Vastutustundliku+laenamise+p\%F5him\%F5te.pdf (most recently accessed on 18.1.2014) (in Estonian).

60 Võlaõigusseaduse ja teiste seaduste muutmise seaduse eelnõu seletuskiri (see Note 57), p. 26.

61 Tarbijakaitseamet (see Note 36), Section 7.

62 Law Enforcement Act (Korrakaitseseadus) - RT I, 22.03.2011, 4 (in Estonian). 
In the legal literature, it is argued that the principle of responsible lending does not oblige the creditor to refrain from giving credit to a non-creditworthy consumer. ${ }^{*} 63$ Neither does such an obligation follow from the wording of $\S 403^{2}$ of the LOA. However, the Supreme Court has referred in a recent decision to the creditor being obliged to refrain from giving credit in cases wherein it should have been obvious to the creditor that extension of the loan term for an additional fee would only increase the debt'. ${ }^{\prime} 64$ The Supreme Court stated that if the creditor had implemented the principle of responsible lending, the plaintiff would have not entered into contract with the creditor and could have avoided the increase of debt'. ${ }^{*} 5$ Accordingly, it seems that the interpretation of the Supreme Court moved beyond the wording of the LOA with the conclusion that the creditor must refrain from granting credit in situations wherein the non-creditworthiness of the consumer is obvious.

\section{Contractual measures}

\subsection{The unconscionability doctrine and relative APRC restrictions}

In 2009, the Estonian legislator tried to solve the problems arising out of usurious practices of instantloan providers through a legislative amendment setting forth a relative APRC cap in combination with the unconscionability doctrine. Before that, the prevailing view in court practice was that the parties are free to agree upon the interest rate of a loan and, therefore, an unproportionally high interest rate does not, in itself, entail violation of 'good morals'. ${ }^{* 66}$ Thus a usurious credit contract could not be considered automatically void under $\$ 86$ of the GPCCA. The position taken by the Supreme Court before 2009 was that such a contract can, as a rule, only be avoidable under $\S 97$ of the GPCCA if the consumer is able to prove that 1) he or she concluded the agreement under extremely unfavourable conditions, 2) he or she did so because of gross disparity (inexperience, urgent needs, etc.), and 3) the other party benefited from the gross disparity. ${ }^{* 67}$ In the legal literature one could also find the view that in electronic credit transactions wherein the creditor does not assess the creditworthiness of the borrower, there should also be a possibility to consider a usurious credit contract void through breach of 'good morals' under $\$ 86$ of the GPCCA. ${ }^{*} 8$ In practice, though, this norm was never applied and credit agreements with high interest costs were held to be valid by the courts.

In February 2009, the Estonian Parliament passed a legislative amendment, affecting $\S 86$ of the GPCCA, with a purpose of 'reducing the social problems related to the rapid development of the instantconsumer-credit market'. ${ }^{69}$ It was admitted that the legal rules in effect at the time were not able to solve those problems in accordance with the social needs and the society'ssense of justice. ${ }^{*} 70$ The amendment entered into force on 1 May 2009 and changed the notion of a transaction violating 'good morals'. The aim with the new wording of $\S 86$ of the GPCCA was to ensure that usurious credit contracts can be considered to be against good morals and hence void.

The new $\$ 86$ (2) of the GPCCA stipulates that a transaction is deemed contrary to good morals if, inter alia, one party knew or had to know that the other party entered into the transaction because of urgent needs, said person's dependence or inexperience, or similar circumstances and if 1 ) the transaction was made on grossly unfair terms for the other party or 2) imbalance in the value of the mutual obligations of the

63 K. Sein. Protection of consumers in consumer-credit contracts: Expectations and reality in Estonia. - Juridica International 2013, p. 37.

64 CCSCd 19.02.2014 3-2-1-169-13, paragraph 21 (in Estonian).

65 Ibid.

66 See CCSCd 22.10.2002 3-2-1-108-02; CCSCd 16.10.2002 3-2-1-80-02; CCSCd 29.01.2007 3-2-1-137-06. See also K. Saare et al. (see Note 17), pp. 136-137.

67 CCSCd 22.10.2002 3-2-1-108-02, paragraph 11 (in Estonian).

68 P. Varul et al. Võlaõigusseadus II. Kommenteeritud väljaanne ['Law of Obligations Act II: Commented Edition']. Tallinn: Juura 2007, pp. 391-392.

69 Tsiviilseadustiku üldosa seaduse ja võlaõigusseaduse muutmise seaduse eelnõu seletuskiri ['Explanatory memorandum on the Act Amending the General Part of the Civil Code Act and Law of Obligations Act']. Available at http://www.riigikogu. ee/?page $=$ eelnou\&op=ems2\&emshelp $=$ true\&eid $=420369 \& u=20130411155159$ (most recently accessed on 10.4.2013) (in Estonian).

70 Ibid. 
parties exists and can be deemed contrary to good morals. In order to ease the consumer's burden of proof, the second sentence of $\S 86$ (3) of the GPCCA stipulates that in the case of consumer-credit contracts it is assumed that the value of the parties' mutual obligations is disproportionate and contrary to good morals if, inter alia, at the time of issuing of the loan the APRC payable by the consumer is more than three times the average APRC charged on consumer credit by credit institutions according to the latest statistics of the Estonian Central Bank. ${ }^{*} 1$

The matter of the burden of proof under the new rule was initially not clear, however. A view was expressed in the literature that if the APRC of a credit agreement exceeds three time the average APRC, it is presumably void and it is for the creditor to prove the opposite-i.e., not having known or been required to have known of the existence of gross disparity. ${ }^{*}$ Such a burden of proof would have been fairly complicated for the creditor to meet, as it would have meant the proof of absence of a circumstance. Therefore, the Estonian Chancellor of Justice went so far as to take the position that $\S 86$ of the GPCCA might violate the fundamental freedom of free entrepreneurship guaranteed by the Estonian Constitution. ${ }^{*} 73$ The issue was finally clarified in 2011 in Supreme Court case 3-2-1-49-11. The Supreme Court stated that, for the credit contract to be held to be against 'good morals' and, accordingly, void under $\S 86$ of the GPCCA, it has to be ascertained, firstly, whether there is a gross imbalance in value in the mutual obligations of the parties and, secondly, whether the consumer concluded the contract in consequence of his or her urgent needs, dependence, or inexperience. ${ }^{*} 4$ Most importantly, the Supreme Court stressed that it is the consumer who has to plead and prove the existence of the second of these elements, i.e. that he or she concluded the contract due to gross disparity. ${ }^{*} 75$

Such division of the burden of proof means that $\S 86$ of the GPCCA, providing for the voidness of a usurious credit contract, cannot be applied ex officio by the court, particularly if the consumer is not present in the proceedings, which is often the case is Estonia. ${ }^{*}{ }^{6}$ This is probably one of the most important reasons for which the unconscionability doctrine has proved to be ineffective against the usurious practices. The fact that it is the consumer who must plead and prove that he or she concluded the credit contract due to urgent needs or inexperience has created a situation in which there are practically no cases wherein the voidness of a usurious credit contract has been established by the court. ${ }^{*} 77$ It is interesting to note, however, that in a judgement of the Tallinn District Court the court held that asserting claims arising from a consumer-credit contract with an APRC of $441 \%$ is not compatible with the principle of good faith. ${ }^{*} 78$ The court explicitly did not apply the unconscionability doctrine of $\S 86$ of the GPCCA, although the arguments put forward in the judgement were, in fact, essentially the same as what can frequently be found in assessment as to the usurious nature of a credit contract. The court was probably trying to avoid the problem of the consumer having not established the existence of gross disparity and, rather, applying the principle of good faith, which could be applied ex officio and without any issues of the burden of proof.

One of the further reasons for which $\S 86$ of the GPCCA is very seldom applied in the case law is that usurious consumer-credit contracts are often enforced not in ordinary court proceedings but through the use of debt-collection agencies. This has psychological background as consumers tend to pay voluntarily after receiving a payment reminder from the debt collectors. ${ }^{*} 79$ Firstly, they are not sure of their legal rights and often find the pressure from the agency intimidating. Secondly, many of them are afraid of the

${ }_{71}$ As of 1 March 2014, the annual interest rate published by the Bank of Estonia for short-term credit (granted in Estonian kroons) (at http://www.eestipank.info/) was 33.96\%. As a result, the contractual APRC is deemed to be contrary to good morals if it amounts to more than about $100 \%$.

72 K. Saare et al. Laenusaaja õiguste kaitse SMS-laenulepingute puhul ['Protection of consumers in SMS loan agreements']. Juridica 2010/1, p. 47 (in Estonian).

73 For further information on this issue, see the work of I. Ulst (see Note 18), pp. 44-77.

74 CCSCd 17.06.2011 3-2-1-49-11, paragraph 8 (in Estonian).

75 Ibid., paragraph 9. The standard of proof may be lower, however, in those cases in which the disproportion between the parties' obligations is extreme.

76 For more information, see K. Sein (see Note 62), p. 34, along with I. Ulst (see Note 18), p. 75.

77 M. Vutt. Tehingu heade kommete vastasus TSÜS $\S 86$ alusel ['Transactions contrary to good morals under $\S 86$ of the GPCCA'], pp. 6-18, 25-26. Available at http://www.riigikohus.ee/vfs/1352/TehinguHeadeKommeteVastasus_MargitVutt.pdf (most recently accessed on 3.4.2013) (in Estonian). See also K. Sein (see Note 62), p. 34.

78 Judgement of the Tallinn District Court 2-11-60438, of 3.1.2012 (in Estonian).

79 K. Sein (see Note 62), p. 34. 
creditor reporting their default to the credit information registry, which would result in their stigmatisation throughout the credit market.

The ordinary court proceedings are avoided also through the use of the order-for-payment procedure. If the creditor uses this procedure and the defaulting consumer does not file a timely statement of opposition to the claim, the court issues a payment order in accordance with $\$ 489$ of the Civil Procedure Code. Such a payment order can be enforced without any other formalities, and thereby the creditor can avoid assessment of the validity of the claim by a court. The fact that the interests of consumers are not adequately protected in the order-for-payment procedure has been repeatedly stressed in the Estonian legal literature. ${ }^{* 80}$ It is also the Estonian reality that most debtors in cases of usurious consumer loans tend to be persons who are not ready to assert their rights in the courts. Their situation is further complicated by the fact that consumer-credit norms are highly complex and consumers are, as a rule, not able to resort to them ${ }^{*} 81$, at least not without professional legal aid.

The norms banning usurious contracts have further been avoided via use of abstract acknowledgements of debt. It is common practice in Estonia that when a consumer defaults, the creditor (or the debt-collection agency hired by the creditor) offers him or her the option of signing an abstract acknowledgement of debt according to which the consumer acknowledges owing the creditor a certain sum of money. In other words, the capital of the debt, the interest, penalty interest, and other costs of the initial contract are added together and constitute the new capital owed under the acknowledgement of debt. ${ }^{*} 82$ These acknowledgements of debt are then enforced either in the order-for-payment procedure or in ordinary court proceedings, which makes it impossible or at least very difficult to determine whether the underlying credit contract could be considered usurious and therefore void under $\$ 86$ of the GPCCA.

All in all, one can draw the conclusion that in reality the unconscionability doctrine and the relative APRC restrictions in $\S 86$ of the GPCCA have not fulfilled their purpose of effectively limiting the usurious practices of electronic-consumer-loan providers. The same view has been expressed by the Estonian Consumer Protection Board. ${ }^{*} 83$ Therefore, a plea has been made in the legal literature to abandon the unconscionability doctrine and to introduce APRC caps in its place. ${ }^{*} 4$ Not all Estonian legal scholars favour APRC restrictions, though. Instead of limitations to the cost of credit and stricter information, disclosure, and prudent marketing requirements are proposed by I. Ulst in her doctoral thesis. ${ }^{*} 85$ She also doubts the constitutionality of APRC or interest-rate restrictions, asserting that 'the APRC limit disproportionately restricts the constitutionally protected right of entrepreneurship freedom of service providers. In weighing the proportionality of the restriction, an important issue is the conflict between the principle of social state and the fundamental right of entrepreneurship freedom'. ${ }^{* 86}$

This far, the Estonian legislator has been unwilling to introduce APRC or interest-rate caps $^{* 87}$ and has instead favoured milder measures such as advertising restrictions or more detailed requirements for responsible lending. As the problem persisted, very recently the Supreme Court intervened and stated that the legislator should foresee APRC caps as a more efficient consumer-protection measure. ${ }^{*} 88$ In the same decision, the Supreme Court partly amended its earlier position, ruling that if the APRC is more than six times the average market consumer-credit APRC, the consumer-credit agreement is presumably in violation of good morals and should, on that basis, be considered void. ${ }^{*}{ }^{89}$ At the end of March 2014, the Ministry

80 K. Saare et al. (see Note 71), p. 49; M. Vutt (see Note 76), p. 6; V. Kõve. Tsiviilkohtumenetluse kiirendamise võimalused ja nendega seotud ohud ['Possibilities for expediting civil proceedings and dangers thereof']. - Juridica 2012/9, pp. 670-671 (in Estonian); K. Sein (see Note 62), pp. 34-35, 39-40.

$81 \quad$ V. Kõve (see Note 79), p. 668.

82 J. Ots. Intressilt viivise arvutamise keeld [Prohibition of calculating penalty interest on interest']. - Juridica 2010/2, p. 422 (in Estonian).

83 Tarbijakaitseamet (Consumer Protection Board). Tarbijakaitseameti aastaaruanne 2010 ['Yearbook of the Consumer Protection Board 2010'], p. 55. Available at http://www.tarbijakaitseamet.ee/public/Aastaaruanne_2010.pdf (most recently accessed on 11.4.2013) (in Estonian).

84 K. Sein (see Note 62), pp. 35-36.

85 I. Ulst (see Note 18), p. 81. Other authors, however, are of the opinion that the regulation of APRC limits is justified for protection of consumers, especially in consideration of the fact that in various European countries similar or even more restrictive interest limits exist; see K. Saareet al. (see Note 71), pp. 141-142.

86 I. Ulst (see Note 18), p. 79.

87 A proposal for a legislative amendment presented by the opposition party to Parliament was rejected in September 2013.

88 CCSCd 5.03.2014, 3-2-1-186-13, paragraph 25 (in Estonian).

89 Ibid., paragraph 22. 
of Justice presented a draft for introduction of APRC caps, which would add a new $\S 406^{2}$ to the Law of Obligations Act. According to the newly drafted $\S 406^{2}$ of the LOA, a consumer-credit agreement would be void if its APRC exceeds triply the average APRC for consumer credit according to the latest statistics of the Estonian Central Bank. At the time of completion of this article, the draft has not yet been adopted, but if it does enter the law, it would probably mean a considerable reduction in usurious credit practices in Estonia.

\subsection{Civil law sanctions for breaching the principle of responsible lending}

In addition to the sanctions in administrative law, breach of the principle of responsible lending can have civil-law consequences in Estonia. Firstly, it has to be stressed that such breach does not render the credit agreement void. ${ }^{*} 90$ But a creditor who is in breach of the responsible lending obligation may be liable for damages calculated on the basis of reliance interest. In late 2012, the Estonian Supreme Court stated that the obligation of the creditor to assess the creditworthiness of the borrower constitutes a pre-contractual obligation under \$14 (1) of the LOA, according to which persons engaged in pre-contractual negotiations or other preparations for entering into a contract shall take reasonable account of one another's interests and rights. ${ }^{* 11}$ If the creditor breaches this pre-contractual obligation, the borrower-and also the person who has given a surety for the borrower-may have a right to damages under Sections 14 and 115 of the LOA. The amount of damages should be assessed on the basis of the negative interest. The borrower should be thus compensated for all negative consequences of the credit-the Supreme Court explicitly names interest for late payment, penalty for breach of contract, and decrease in assets-and can offset the associated claim for damages with the repayment claim of the creditor. ${ }^{*}{ }^{* 2}$ Whether the contractual interest should also be considered worthy of compensation as damages is less clear, but the question should still be answered in the affirmative. ${ }^{*} 93$

It is yet to be decided in court practice whether breach of the responsible lending obligation can also lead to the avoidability (due to mistake or fraud) of the credit contract. ${ }^{*} 4$ Most probably, this should be possible. In 2013, the Tallinn District Court established the legality of avoidance of a mortgage agreement by reason of fraud of the creditor under $\S 95$ of the GPCCA. ${ }^{*} 95$ The court held that the failure of the creditor to assess the creditworthiness of the borrower constituted fraud in the circumstances of the case-the creditor was aware of the over-indebtedness of the borrower-and entitled the mortgagor to avoid the mortgage agreement. The creditor tried to bring the case to the Supreme Court but failed: the Supreme Court decided not to hear the case. The refusal of the Supreme Court to decide on that case indicates that the Tallinn District Court had applied the substantive law correctly: breach of the responsible lending obligation can indeed lead to the avoidance (on account of fraud) of a mortgage agreement. ${ }^{*}{ }^{6}$ But if the avoidance of a mortgage or suretyship agreement is held to be possible (there has even been talk of the principle of responsible surety-taking to go along with the principle of responsible lending), the same should apply to the possibility of avoidance of the credit contract in the first place.

All in all, the civil-law sanctions for breaching the responsible lending obligation can be described as relatively far-reaching under Estonian law: the consumer is, in principle, entitled to avoid the credit contract and claim damages for reliance interest. Further, the legislative amendment of $\$ 403^{2}(7)$ of the LOA dating from 1 July 2013 clarified the issue of the burden of proof, specifying that it is the creditor who has to prove having complied with the responsible lending obligations. It is yet to be seen, however, whether those private-law sanctions will prove to be effective in case law or whether their application will be impeded by procedural issues. Thus far, we have found only one judgement in which a court has actually held the

$90 \quad$ CCSCd 19.02.2014 3-2-1-169-13, paragraph 18 (in Estonian).

91 CCSCd 27.11.2012 3-2-1-136-12, paragraph 24 (in Estonian).

92 Ibid., paragraph 25 (in Estonian).

93 In the legal literature this was held to be possible already in 2007, before the adoption and implementation of the CCD. See P. Varul et al. (see Note 67), p. 383.

94 See also K. Sein. Transposition of the new Consumer Credit Directive in Estonia. - European Review of Private Law 2012/2, pp. 439-440.

95 Judgement of the Tallinn District Court 2-10-48441, of 30.5.2013.

96 The Supreme Court has also held that the avoidance of a personal suretyship agreement for reasons of fraud or mistake is possible; see CCSCd 27.11.2012 3-2-1-136-12, paragraph 26. 
creditor to be in breach of the responsible lending obligation. ${ }^{*}{ }^{97}$ In all other civil cases wherein the issue was considered, the court held that there was no breach of responsible lending, in some cases even stressing that the borrower must be able to assess his or her own creditworthiness. ${ }^{*} 98$

\subsection{Party autonomy restrictions: Interest for late payment and claims for damages}

\subsubsection{Interest for late payment}

The Estonian legislator and the Supreme Court have tried to improve the position of the consumer by restricting party autonomy in several respects. Mostly, the restrictions on party autonomy are related to interest for late payment and a creditor's claim for damages. Some of the restrictions apply to standard terms only, but most of them are relevant also for individually negotiated contracts.

When the consumer is in default on payment, the creditor is entitled to claim interest for late payment under $\S 113$ of the LOA. At first, after the passing of the LOA in 2002, there was no unanimity in views as to whether the creditor may demand interest plus penalty interest in the event of the consumer's default. The clarification came with the judgements of the Supreme Court ruling that the contractual interest can only be claimed until the sum for repayment is due-i.e., only for the time that was originally agreed upon for the use of the creditor's money. If the loan or part thereof is not repaid in time, from this point on the creditor is only entitled to interest for late payment and, as the case may be, for additional damages resulting from the delay. Thus the general rule under Estonian law is that interest for late payment cannot be claimed in combination with contractual interest for the time of default on repayment of the loan. ${ }^{*} 99$ This rule is, in principle, dispositive in nature, so the parties can agree in the contract that the lender is entitled to claim the contractual interest alongside interest for late payment. ${ }^{*}{ }^{* 100}$ The party autonomy ends, however, at the point when the creditor has withdrawn from the contract because of the consumer's default: on account of the mandatory provisions of $\S 416$ (3) of the LOA, the creditor is then only entitled to interest for late payment and cannot claim the lost contractual interest as damages. ${ }^{* 101}$ All in all, the general rule under Estonian law is that in the case of default, the creditor may claim-in addition to specific performance-only interest for late payment.

The restrictions place great weight on how the rate of interest for late payment is calculated. Usually, it is stipulated in the credit contract. Here again, party autonomy is somewhat restricted: according to $\$ 415$ (1) of the LOA, the rate of interest for late payment in consumer-credit agreements may not exceed the statutory rate provided for in \$113 (1) of the LOA. This too has created some controversy in past case law, as $\$ 113$ (1) of the LOA actually covers two methods for calculating the statutory interest rate for late payment. According to the first sentence of $\$ 113$ (1) of the LOA, the statutory penalty rate is calculated by adding eight per cent to the statutory interest rate specified in $\S 94$ of the LOA. ${ }^{*} 102$ For credit agreements, an alternative calculation method is provided for in the third sentence of $\$ 113$ of the LOA: if a contractual interest rate exceeds the statutory rate of interest for late payment, then the contractual interest rate constitutes the rate of interest for late payment. Therefore, if the contractual interest rate as of today exceeds $8.25 \%$, the contractual interest rate will be applied as the rate of interest for late payment. ${ }^{* 103}$

\footnotetext{
97 Judgement of Pärnu County Court 2-10-51549, of 7.6.2013. The Supreme Court found the creditor in breach of the responsible lending obligation also in case 3-2-1-169-13 but dismissed that argument due to procedural reasons.

98 See, for example, Harju County Court judgements 2-12-32459, of 22.4.2013, and 2-12-22941, of 28.2.2013.

99 CCSCd 29.01.2007 3-2-1-137-06, paragraph 17 (in Estonian); CCSCd 5.11.20018 3-2-1-89-08, paragraph 15 (in Estonian).

100 P. Varul et al. (see Note 67), p. 394.

101 CCSCd 14.01.2009 3-2-1-120-08, paragraph 11 (in Estonian).

102 According to Section 94 (1) of the LOA, the interest rate shall be applied on a half-year basis and shall be equal to the last interest rate applicable to the main refinancing operations of the European Central Bank before 1 January or 1 July of the year, unless the law or the contract provides otherwise. The statutory interest rate referred to in Section 94 of the LOA is published on the Web site of the Estonian Central Bank at http://www.eestipank.ee/pub/en/yldine/ekp/ and may change every six months.

103 This was affirmed in Supreme Court judgement 14.01.2009 3-2-1-120-08, paragraph 12.
} 
There is a further restriction on claiming interest for late payment; according to the mandatory $\$ 113$ (6) of the LOA, no interest for late payment may be claimed for delay in the payment of interest. ${ }^{*} 104$ While this does not preclude or restrict the right of the creditor to claim compensation for damage caused by a delay in the payment of interest (see the LOA's $\$ 113$ (7) and §415 (1), second sentence), here the creditor bears the burden of proof as to the existence and amount of his or her damages. And, as we saw earlier, the Supreme Court does not allow the creditor to claim lost contractual interest as damages. ${ }^{*} 105$

Since the financial crisis in 2008, disputes on so-called refinancing agreements have become common. Refinancing agreements are usually concluded in a situation wherein the consumer is not able to pay back the original loan and his or her unpaid debts under the original credit agreement are 'refinanced'; i.e., the payment period is extended. It is common practice that in this situation the unpaid interest (and sometimes also the accrued interest for late payment) is capitalised; i.e., it is added to the capital of the loan. Thus, under the refinancing agreement, the consumer is obliged to pay interest also on the interest accrued under the original credit contract.

Controversy has arisen in case law as to whether such a refinancing agreement constitutes a new credit agreement or should be viewed only as an agreement to change the original credit agreement (to extend the payment period). There was also no common view on whether the practice of capitalising the interest is legal or not. This issue was cleared up by the very recent Supreme Court judgement 3-2-1-169-13. Here, the Supreme Court stated that the legal nature of such agreements should be evaluated on the basis of their economic content and that they should rather be considered modification of the original loan agreement. ${ }^{*} 106$ Secondly, the Supreme Court considered capitalisation of interest (including interest for late payment) unacceptable: such practice is contrary to the prohibition expressed in $\$ 113$ (6) of the LOA. ${ }^{* 107}$ The Supreme Court emphasised that this provision shall not be avoided merely by replacing one agreement with another. Accordingly, it is only allowed to calculate the agreed interest and interest for late payment on the original capital of the loan. ${ }^{* 108}$

Estonian law also entitles the court to reduce the interest for late payment: according to \$113 (8) of the LOA, a person required to pay interest for late payment may claim for a reduction of the fine pursuant to the provisions of $\$ 162$ of the LOA. ${ }^{*} 109$ However, the court may not do so on its own initiative; the debtor must so request. ${ }^{*}{ }^{* 10}$ When deciding upon reduction, the court must consider circumstances such as the extent to which the obligation has been performed by the debtor, the legitimate interests of the creditor, and the economic situation of the parties (see $\$ 162$ (1) of the LOA). If the amount of interest for late payment exceeds the capital of the claim, then the creditor has to prove having suffered loss in a larger amount. ${ }^{* 11}$

As we have seen, claims for interest for late payment are restricted in several ways in Estonian law: firstly, when agreeing upon its rate, the parties must follow the restrictions of $\$ 415$ (1) of the LOA; secondly, the creditor may not claim contractual interest in parallel with the interest for late payment; thirdly, no interest for late payment may be claimed for delay in the payment of interest; and, finally, the court is entitled to reduce the interest for late payment if the consumer so requests.

\subsubsection{Contractual penalties and claims for damages}

Restrictions to party autonomy exist also with respect to liquidated damages claims and contractual penalties. The lead here has been taken by the Supreme Court, who have acknowledged the dangers associated with absolute party autonomy and declared void several abusive clauses in consumer-credit contracts. At

\footnotetext{
104 This has been criticised by P. Varul et al. See Võlaõigusseadus I. Kommenteeritud väljaanne ['Law of Obligations Act I: Commented Edition']. Tallinn: Juura 2006, p. 382; J. Ots (see Note 81), pp. 418-426. In 2009, the Ministry of Justice even presented a draft for elimination of this restriction. However, in the time of financial recession this was politically undesirable, and the law has remained unchanged thus far.

105 CCSCd 14.01.2009 3-2-1-120-08, paragraph 11.

106 CCSCd 19.02.2014 3-2-1-169-13, paragraph 17 (in Estonian).

107 Ibid., paragraphs 28-30.

108 Ibid., paragraph 29.

109 The court may also reduce the statutory interest for late payment calculated in accordance with the third sentence of Section 113 (1) of the LOA. See CCSCd 3-2-1-120-08 (see Note 98), paragraph 12.

110 P. Varul et al. (see Note 103), p. 383; CCSCd 14.06.2005 3-2-1-66-05, paragraph 15 (in Estonian).

111 CCSCd 14.06.2005 3-2-1-66-o5, paragraph 18.
} 
least once, the position taken by the Supreme Court has brought about amendments to the Law of Obligations Act. Namely, before 2008, it was common practice for creditors offering usurious electronic consumer credit to provide for a contractual penalty for late payment and for this to be claimed in addition to the interest on late payment. ${ }^{* 112}$ In 2008, such clauses were declared void by the Supreme Court in case 3-2-1120-08 as being contrary to the mandatory provisions of the consumer-credit contract law ( $\$ \S 416$ and 421 of the LOA). ${ }^{* 113}$ After this judgement, in 2011, a provision was added to the LOA precluding such contract terms: according to the new third sentence of $\$ 415$ (1) of the LOA, agreements that allow claiming payment of earnest money or a contractual penalty from the consumer in the event of late payments are void.

Very often, the position of consumers who are in default is worsened by the high debt-collection and payment-reminder fees that they are bound to pay under the standard terms of the creditors. In the abovementioned groundbreaking case, 3-2-1-120-08, the Supreme Court tried to stop the practice of creditors charging unreasonably high fees for debt collection and payment reminders as liquidated damages. The Supreme Court ruled that clauses according to which consumers have to compensate for debt-collection and payment-reminder fees as fixed in the standard terms of the creditor can be deemed unfair under $\$ 42$ (3), item 5 of the LOA if they are unreasonably high. ${ }^{*} 14$ However, there remains no common understanding in the case law of when such collection costs can be considered unreasonably high and the clauses, for this reason, void. ${ }^{*} 15$ One can find decisions wherein the courts have found such costs to be unreasonably high and, accordingly, unfair, with the consequence that the consumer does not have to bear them or has to compensate for them to only a reduced extent. ${ }^{*} 116$ In the majority of the cases, however, courts have held the clauses to be valid, ordering the consumers to pay relatively large amounts of collections costs. ${ }^{*} 17$

The absence of uniform case law on debt-collection fees stems from the fact that Estonian law does not provide for clear criteria in decisions on the possible unfairness of the liquidated-damages clauses pertaining to debt-collection fees. Therefore, there has been discussion of whether one should follow the example of several European countries (such as the Nordic countries or Holland) where maximum amounts of debtcollection costs are specified by law. The Ministry of Justice has done preliminary research on the issue and put forward a proposal to the legislature, but this proposal has not yet been adopted by the Parliament.

\section{Penal measures}

There are no measures in penal law in the Estonian law that could be applied in cases of usurious credit contracts or of breach of the responsible lending obligation. Usury is not considered a criminal offence under the Estonian Penal Code.

\section{Conclusions}

Instant loans are a fairly new phenomenon in the Estonian credit market. Regardless of the absence of statistical data of any precision, it is obvious that the problem of over-indebtedness is a very topical question.

Instant-loan providers are currently neither supervised by the Financial Supervision Authority in Estonia nor subject to a licensing system. Therefore, there are no official statistics on the exact number of borrowers; one can provide only some estimates. The market share of electronic retail lenders is about $16 \%$ of

112 K. Sein (see Note 62), p. 38.

113 CCSCd 14.01.2009 3-2-1-120-08, paragraph 15 .

114 Ibid.

115 K. Saare, K. Sein. Amtsermittlungspflicht der nationalen Gerichte bei der Kontrolle von missbräuchlichen Klauseln in Verbraucherverträgen ['Obligation of national courts to act ex officio by unfair terms control in consumer contracts']. - Zeitschrift für Europäisches Unternehmens- und Verbraucherrecht 2013/1, p. 24 (in German).

116 E.g., Tartu County Court decisions 2-o8-14356 and 2-11-19661, wherein the Court considered 3,100-kroon (approx. 199 EUR) and 166.14 EUR debt-collection fees to be unreasonably high. Collection costs of 126 EUR were deemed unreasonably high also in a recent decision of Pärnu County Court (2-13-765, of 13.9.2013).

117 See, for example, decision of Harju County Court 2-07-3204, in which the creditor was awarded EUR 86.92 in debt-collection fees. 
the whole retail lending market. However, according to various assessments, there might be approximately 100,000 customers of instant-loan providers, with their number continuously growing.

Estonian law provides some specific restrictions on advertising of financial services and some general requirements for marketing that have an impact on the instant-loan market. In 2013, the legislator set forth additional requirements in relation to advertising of financial services. Also, the responsible lending principle and expanded information obligations were added in the transposition of the EU Consumer Credit Directive. In addition to the administrative-law sanctions, breach of the principle of responsible lending can have civil-law consequences in Estonia-loan providers may be liable for damages calculated on the basis of reliance interest.

Debt-counselling as a social service is not generally available in Estonia. However, there is access to some privately organised debt-counselling systems. Only a privately held negative credit register exists in Estonia, but there is some discussion of the possibility of introducing a positive credit register.

In 2009, the Estonian legislator attempted to solve the problems arising out of usurious practices of instant-loan providers by means of a legislative amendment setting forth a relative APRC cap in combination with the unconscionability doctrine. In reality, the latter doctrine and the relative APRC restrictions have not fulfilled their purpose of effectively limiting the usurious practices of electronic-consumer-loan providers. Thus far, the Estonian legislator has been unwilling to introduce APRC or interest-rate caps. Rather, it has favoured lighter measures such as advertising restrictions or more detailed requirements for responsible lending. With the problem not having gone away, very recently a draft was presented by the Estonian Ministry of Justice with proposed introduction of an APRC cap, which should be triply the market average APRC. Should this proposal be accepted, it might lead to a considerable reduction in usurious credit practices in Estonia. Its effectiveness might, on the other hand, be reduced in consequence of use of the order-for-payment procedure remaining possible for consumer credit regardless of the APRC of a given contract. Other positive developments are the proposals for specified ceilings to debt-collection costs, for introducing licensing requirements for creditors and for additional restrictions on advertising. 